\title{
You Can't Eat Biodiversity: Agency and Irrational Norms in European Aquatic Environmental Law
}

\author{
Tim O'Higgins \\ Marine Governace Group, MaREI, Environmental Research Institute, University College Cork, Cork, Ireland. \\ E-Mail: tim.ohiggins@ucc.ie; Tel.: +353214864324
}

Submitted: 20 March 2016 | In revised form: 21 July 2016 | Accepted: 12 October 2016 | Published: 19 March 2017

\begin{abstract}
Policies of the European Union cover a range of social, environmental and economic aspirations and the current environmental directives and laws have evolved from a suite of norms which have changed over time. These may be characterised loosely according to 'Three Ps': Practical, those taking an anthropocentric approach; Pure, those taking an ecocentric approach and Popular, those appealing to the general public. In this paper I use these three perspectives as a tool to analyse the complexity and identify contradictions in European aquatic environmental legislation. Some trade-offs between development and conservation are identified and used to characterise the potential qualities of more successful agency to achieve environmental goals in the governance of European aquatic environments.
\end{abstract}

Keywords: biodiversity; environmental policy; ecosystem services; transformation

\section{Argument: Human Development and Evolving Norms}

The normative role of sustainability science, by all modern definitions, is that of balancing conservation of the environment with sustainable use, where sustainable development is defined as meeting current needs without compromising the needs of the future $[1,2]$. The Sustainable Development Goals (SDGs) set out the most comprehensive suite of 17 social, economic and environmental goals and 169 targets to which sustainability science might aspire. Achieving these goals is a major challenge for humanity. At current efficiencies of resource use, and with current patterns of resource distribution in global society, the goals of eliminating poverty and hunger, promoting equality, providing jobs, economic infrastructure and growth all demand an increase in the resources available to many of the world's seven billion population. At the same time, considerations of ecological footprints suggest that many wealthier na- tions are living beyond sustainable levels of consumption $[3,4]$ and will need to decrease these levels to achieve sustainability. Against this backdrop of global inequality, biodiversity globally is declining as humans continue to appropriate undeveloped areas [5]. At the core of sustainability science lie trade-offs between equitability and affluence as well as human use and non-use of natural resources. These trade-offs are 'wicked problems' which will involve winners and losers, and their solutions require moral judgments [6].

In 1992 the Convention on Biodiversity (CBD) recognised the "intrinsic value" of the diversity of life [1], which ultimately contributed to the SDGs recognising the "integrated and indivisible' balance between social economic and environmental aspects of sustainability [2].The current outlook on the role of man and nature set out in the SDGs has changed considerably since the inception of the European project following World War II. At that time, human population was approaching the peak of its growth [7] with the pop- 
ulation movement (successor to the eugenics movement and precursor to the modern environmental movement) advocating direct population control in a resource constrained planet [8-11] while the "green revolution" successfully set about improving agricultural yields [12,13]. However, this intensification of agricultural production has led to increasing environmental degradation of terrestrial and aquatic habitats [14-19] and these growing global pressures brought into focus the increasing rate of species extinctions $[19,20]$.

The prevailing narrative in modern conservation science connects biodiversity with ecosystem processes and human well-being through ecosystem services, the benefits obtained by humans from nature. These may be divided into supporting, regulating, provisioning and cultural services [21,22]. The benefits provided by ecosystem services may be further categorised as active or passive use values as well as non-use values such as existence, option and bequest values [23]. This narrative accommodates the norms of the SDGs recognising that social systems are connected to ecological systems and viewing biodiversity as an underpinning natural resource enabling development. There remains, however, great uncertainty about the mechanisms connecting biodiversity to ecosystem processes, ecosystem services and benefits [5,24]. Despite ongoing global declines in biodiversity and ecosystem services, human well-being at the global level has continued to increase, which may be due to the reliance of well-being on food production, the decoupling of well-being from nature through technology, or time-lags between the loss of biodiversity and its consequences in terms of well-being [25].

The EU Biodiversity strategy [26], successor to the Biodiversity Action Plan [27], aims to halt biodiversity loss within Europe and stop global biodiversity loss by 2020 in line with SDGs 14 and 15, the protection and sustainable use of the oceans, and terrestrial environments respectively. The EU strategy [26] was developed to provide Europe with a mechanism to achieve its commitments under the CBD. Meeting the goals of the biodiversity strategy through the use of existing environmental legislation and the development of new legislation in Europe requires joining together many different environmental laws and policies, which have developed alongside the shifting norms described above. Norms are considered here in the general sense as sets of societal values or standards.

The shifting role of biological science in social development, through the eugenics, population and subsequent environmental movements, has left a legacy of economics, politics and legislation which have formed the current models for Earth system's governance and have potential to enable, or to hamper, productive development of environmental governance systems. Changing norms have shaped European environment and development policies over time, and the application of environmental regulation has led to social and political trade-offs, generally favouring economic development (sustainable or otherwise).

Europe has been hailed as a leader in environmental protection [28] and the quest for sustainability, yet despite a wide range of legislative measures and environmental protection policies, the European Biodiversity Strategy is failing [29]. Traditionally environmental science has been reactive [30], i.e. problems are usually identified and a solution is found to address the specific problem. Yet to achieve sustainability, it is increasingly recognised that a more proactive, transformative approach is required where there is a coherent vision of a sustainable future [31]. Normative analysis of existing policies can therefore serve as a baseline to assess the values on which existing environmental policies have developed and to compare these to current aspirations or visions such as those set out in the SDGs or under the EU Biodiversity Strategy. Explicit recognition of the multiple competing values underlying different initiatives which aspire to sustainability, can serve as a firststep to analysing policy coherence, aligning multiple policy objectives and institutional recognition of the range of divergent norms in existing policies. As such normative policy analysis can act as a useful starting point for institutional transformation.

While the SDGs 14 and 15, and the Biodiversity Strategy set the mission of achieving sustainability in terms of reducing biodiversity loss, the legal mandate for sustainability in EU member states is determined by environmental laws and directives. The pathways toward sustainability are dependent on the current levels of sustainability (the status quo) and the trajectories toward sustainability are dependent on the legacy of historic and existing practices. For practical purposes, the legal mandate of sustainability science is enshrined in the legislation and understanding how this legislation has developed is therefore critical to assessing the changes required to meet the goals of the mission.

The aim of this paper is to identify the norms informing environmental legislation in the European context with a particular focus on their relevance to the biodiversity strategy in marine and freshwater aquatic environments. Three dominant themes in European environmental legislation are identified. These norms are traced through the development of environmental legislation, and the implications for these norms in developing effective agency in environmental management is explored.

\section{Analysis and Discussion}

\subsection{A Normative Classification of Environmental Policy}

Sustainable development is often represented as having three distinct interrelated components: economy, environment and society. The model presented by Giddings et al., [32] of concentric circles with environment containing society, and society containing economy, represents an ideal frame, but in practice disciplinary silos generally result in a range of more fragmented perspectives. Some authors [33] have distinguished between the techno-economic, socio-cultural and bio-ecological elements which go into 
environmental decision making. This study takes the perspective that these three competing sets (economic, social and ecological elements) relate to values or norms which are transcribed into three types of environmental policy, termed here Practical, Popular and Pure respectively and that these can be distinguished by their focus on the management of different ecosystem services or on biodiversity.

Environmental policies with an anthropocentric focus may be considered Practical. Practical norms are largely aligned with natural resource management concepts, for example, management of stocks to meet human ends, through the exploitation or stewardship of the natural environment. These may be loosely aligned with the concept of economic well-being, where individuals seek to maximize their own profits or production. Practical policies often relate to the systematic use of provisioning ecosystem services. In this analysis policies are considered to fall into this category if their primary focus is on natural resource extraction and management.

Some components of conservation or sustainability resonate more easily with the general public than others. Popular norms are defined by their focus on cultural ecosystem services. This impact of these policies may be associated with non-use cultural ecosystem services for example with species that are highly visible, the "warm glow" [34] of protecting charismatic species, such as the giant panda, the polar bear or cetaceans, which elicit strong responses toward conservation. Similarly, sustainability policies which have clear impacts on direct use cultural services where, public goods are directly used by individuals without the intermediary of a specific economic sector (e.g. recreational fishing, swimming), may be considered popular as they relate to the public good rather than economic development of any particular specific sector. The values or cultural ecosystem services associated with these conservation norms may not necessarily be aligned with scientific justification (e.g. Potts et al.) [35]. Regulations and policies, which implicitly focus principally on cultural ecosystem services or components of ecosystems, which supply these services, are categorised in this analysis as Popular.

The Pure perspective is encapsulated by the slogan adopted by the US environmental movement of the early 1970s "we have met the enemy and he is us". This viewpoint considers human activities as inimical to ecosystem functions, juxtaposing man against nature. The norms associated with this narrative of purity seeks a return to preanthropogenic disturbance. This concept of naturalness or purity often represents the norm of the hard environmental conservationists and, as in the $\mathrm{CBD}$, recognises the "intrinsic worth" of the natural environment. Policies which aim to minimize or eliminate human effects, principally for the sake of the environment itself or for its 'intrinsic value', are categorised as Pure in this analysis.

Individual pieces of European legislation may be $\mathrm{Hy}$ brids exhibiting a mixture of the three characteristics described above. Table 1 summarises the main pieces of
EU environmental legislation directly related to the aquatic environments. These pieces of legislation were mapped against the norms described above based on their relation to the use of ecosystem services. Policies were classified as either Practical or Popular where they address management of provisioning, or cultural services respectively. The policies were categorised as Pure where they treat ecological integrity as an end in itself, the texts of the legislation were also analysed for explicit statements relating to economic, social, and environmental values. Figure 1 maps the legislation onto a Venn diagram of the three value sets. The following section provides an historical narrative on the development of the legislation over time, under headings of the three norms.

Table 1. Major Directives relating to the EU biodiversity Strategy in the Aquatic environment.

\begin{tabular}{lrc}
\hline Policy/Directive/Regulation & Acronym & Year \\
\hline Common Agricultural Policy & CAP & 1962 \\
Bathing Water Directive & BWD & 1976 \\
Birds Directive & BD & 1979 \\
Common Fisheries Policy & CFP & 1983 \\
Urban Waste Water Treatment Directive & UWWTD & 1991 \\
Nitrates Directive & ND & 1991 \\
Habitats Directive & HD & 1992 \\
Water Framework Directive & WFD & 2000 \\
Marine Strategy Framework Directive & MSFD & 2008 \\
Regulation on Alien Invasive Species & IAS & 2014 \\
\hline
\end{tabular}

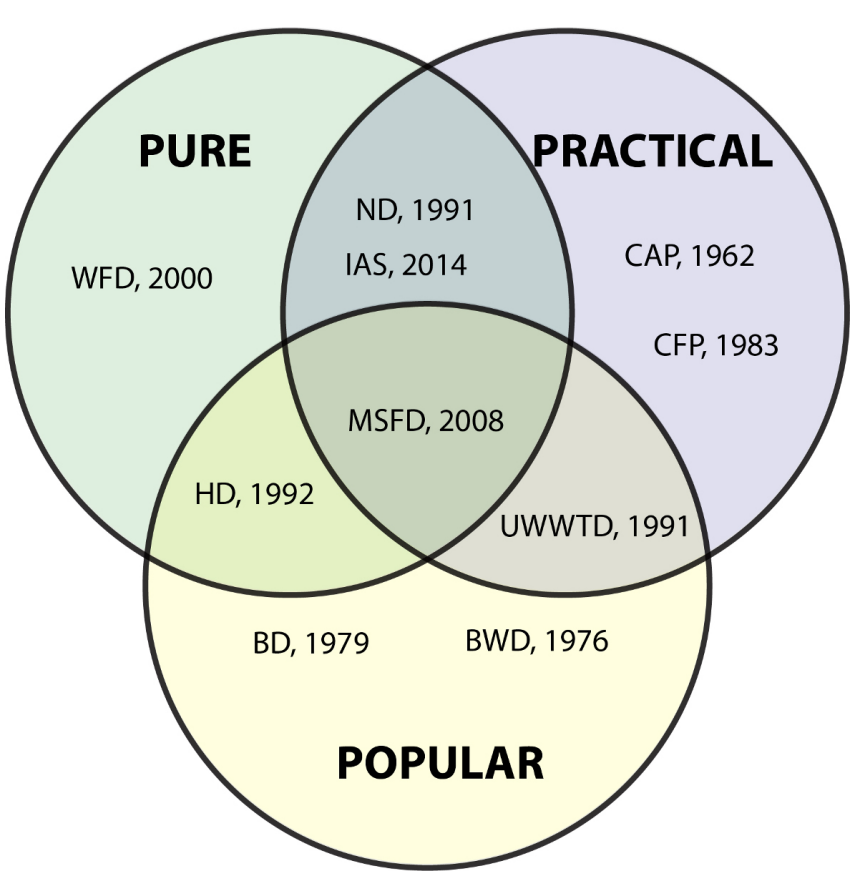

Figure 1. Venn diagram showing the overlap in values between different EU environmental directive and policies relating to the biodiversity in aquatic environments. 


\subsection{Practical}

Though not a policy explicitly directed at the management of the aquatic environment, agricultural nutrient sources play a major role in determining European water quality [36] and for this reason the Common Agricultural Policy cannot be omitted from any analysis of aquatic environmental policy in Europe. The CAP, with the aims of achieving food security in Europe through modernization and ensuring good prices for farmers, was put in place in 1962 and since its inception food security within Europe has been maintained [37]. The CAP includes subsidies to farmers as well as import tariffs to ensure prices for European farmers. The early CAP was criticised as a protectionist policy having created price distortions in global food markets [38] but recent revisions have removed some of the more distorting subsidies [39]. The CAP has a budget of $€ 362.8$ billion (almost $40 \%$ of the EU's budget) to subsidise agriculture in the period 2014-2020 [40]. In its current form the policy is comprised of two 'pillars', direct payments or subsidies which make up $70 \%$ of the CAP budget and the European Agricultural Fund for Rural Development (EAFRD), which accounts for the remaining 30\% and provides co-funding for national programmes of rural development [41]. In addition to continued food production, the most recent reforms in the CAP aimed to encourage farmers to provide public goods, enhance biodiversity and play a role in climate mitigation. $30 \%$ of direct payments are now nominally conditional on greening measures, including maintenance of permanent grasslands and crop diversification, in practice most farms, particularly smaller ones, are exempted from having to take any action to receive these subsidies [42]. This proportion of the CAP budget assigned to the production of food (a provisioning service) clearly categorises the CAP as a Practical policy.

A Common Fisheries Policy (CFP) began to emerge in the late 1970s as new member states joined the European
Economic Community, catalysing arrangements for existing member states to gain free access to community fishing grounds. The CFP was formalised in 1983 [43] and has subsequently undergone a number of reforms $[44,45]$. Fisheries under the policy aim to achieve Maximum Sustainable Yield (MSY). This objective has been criticised both on an economic basis (theoretically a more efficient fishery would aim for Maximum Economic Yield) as well as on a technical basis, achieving MSY in a mixed species fishery is notoriously difficult to achieve. The operation of the CFP itself has also been heavily criticized on many fronts, in particular for the systematic rejection of scientific advice on catch levels [46]. In recent years for example catches have on average been set $20 \%$ higher than the scientific advice [47], as national political interests try to ensure the best deal for their national fishing industries. The setting of quotas has also led to the practice of discarding, which is now banned under the most recent reforms [48], which marking a shift toward Ecosystem-based management. There has been a long history of dysfunction in the CFP, currently $58 \%$ of assessed commercial stocks are considered to be at levels below levels of MSY [49] though some stocks are beginning to recover [50]. The target of MSY clearly marks the CFP as a Practical policy since the aim is to maximize the amounts of fish extracted from the seas.

The European project was designed as a free trade organisation to facilitate trade between European nations, with the goals of averting war mainly through economic means [51] and ensuring that the major policies controlling sustainable development continue to have a chiefly economic outlook. Figure 2 illustrates the budget breakdown for sustainable growth and natural resources in the EU for 2015 , the total budget is over $€ 55.9$ billion. Components of the CAP combined with those of CFP make up over $99 \%$ ( $97.5 \%$ and $1.68 \%$ respectively) of this budget, less than $1 \%$ is assigned to other aspects (including environment and climate programs).

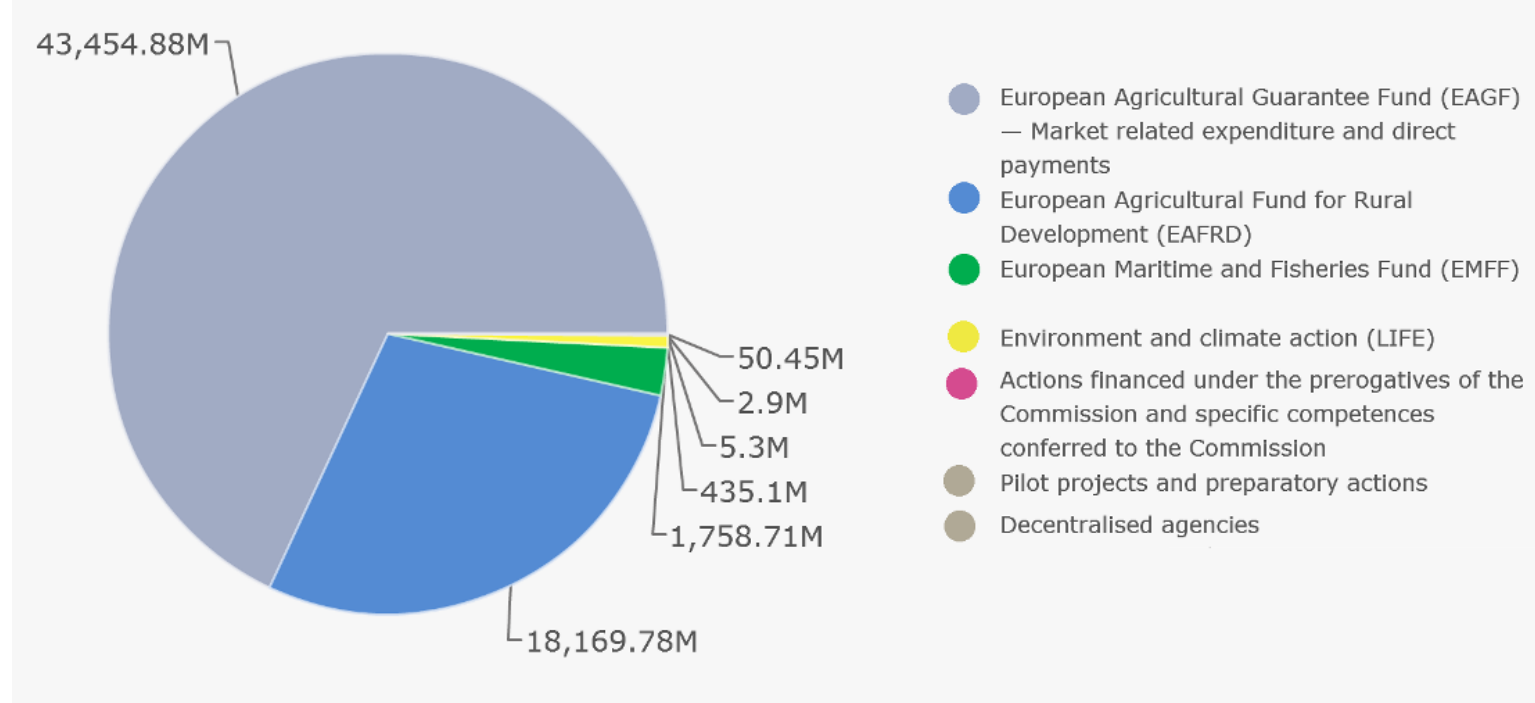

Figure 2. Sustainable growth: natural resources budget for the EU 2015 [52]. 
Conservation measures under "Greening of the CAP" and reformed CFP have placed the expectation on farmers and fishers to be the major agents of biodiversity conservation. Following half a century of centrally facilitated intensification administered at the level of nation states, this marks a major shift in expectation, which has not been backed up by institutional support.

\subsection{Popular}

The first pieces of EU law aimed at improving aquatic environmental quality was the Bathing Water Directive. It was introduced "in order to protect the environment and public health" [53]. The directive sets limits on the levels of bacteria (coliforms and enterococci) which are permitted to occur at locations designated for public bathing, in fresh and marine waters. Compliance with the directive has been supported by the European Commission since 1987 through the Blue Flag program which promotes public awareness; beaches which comply with water quality standards (and certain other criteria) are awarded a blue flag for cleanliness. The implicit focus of the directive on (direct use) cultural ecosystem services categorises the Bathing Water Directive as Popular.

The Birds Directive was established in 1979 [54] and updated in 2009 [55] to halt the decline in the numbers of wild bird species in the EU, this trend is largely ascribed to agricultural intensification [56]. The directive lists various species which must be conserved (Annex I) and others which may be harvested subject to certain conditions (Annex II) and designates Specially Protected Areas (SPAs). Both "natural balance" and "cultural heritage" are motivations for the Directive [54], the latter, illustrates the Popular nature of the directive. Article 2 of the directive mandates that bird species are maintained at "a level which corresponds in particular to ecological, scientific and cultural requirements, while taking account of economic and recreational requirements, or to adapt the population of these species to that level". The perspective of the Birds Directive includes both ecological and cultural considerations but its focus on "recreational and cultural requirements", as well as its scope covering on popularly appealing, charismatic species, which provide active and passive use cultural ecosystem services, makes the case for its inclusion in the popular set. Despite its early introduction, EU avian biodiversity continues to be eroded [57].

\subsection{Pure}

The Water Framework Directive (WFD) was introduced [58] to harmonise the growing body of aquatic environmental legislation. This directive regulates water quality in freshwaters (rivers, lakes and groundwater) and saltwater (estuarine and coastal) areas. The goal of the directive is to achieve or maintain Good Ecological Status, which is defined with reference to a relatively clean or pristine reference condition, (determining reference conditions is itself a value laden process). The directive takes a 'deconstructing structural' approach $[58,59]$ dealing with the characteristics of specific elements of water quality. These water quality elements are measured by a suite of indicators which include chemical parameters (concentrations of nutrients and oxygen) as well as biological parameters such as the composition of aquatic benthic flora/fauna, fauna the abundance of specific sensitive insect species for freshwater and benthic in-fauna in the marine. Given the long history of human settlement and development in Europe, aquatic ecosystems have been experiencing anthropogenic disturbance for millennia [60], and to some the goal of good ecological status is a 'dream' [61], particularly given the non-linear responses of aquatic system to relaxation of anthropogenic pressures [62]. The WFD permits the designation of heavily modified water bodies, where specified uses of water bodies (including navigation, hydro-power, and recreation) would be significantly affected by restoration measures and no feasible cost-effective option exists that would maintain these benefits [59,63]. Nevertheless, since its introduction, the directive has resulted in a major concerted effort in the measurement and monitoring for the improvement of the quality of water bodies around Europe [18]. The norms of the directive are clearly Pure as they aspire to achieving pre-anthropogenic conditions, with baseline targets set on ecological rather than anthropocentric grounds.

\subsection{Hybrids}

The Nitrates Directive [64] deals directly with the prevention of undesirable emissions from the "Practical" CAP for the sake of achieving environmental quality, hence its inclusion in the subset of Practical and Pure. Measures to ensure compliance with the nitrates directive include the creation of buffer strips in farm land to prevent agricultural run-off. In practice the success of the Nitrates Directive is complicated by the difficulties in enforcement of local actions over the large spatial scales covered by the Directive [65]. The nitrates directive is considered to have reduced nitrogen outputs from agriculture by between $3 \%$ and 19\% depending on the species of nitrogen considered [66].

The Urban Waste-Water Treatment Directives [67], (UWWT) provides for end of pipe solutions to the release of polluted waste waters. The maintenance of clean water has elements of Practical natural resource management (supply of a provisioning service for human health) and Popular aspects in terms of supply of clean water for cultural service such as bathing and is therefore classified as a hybrid of practical and pure.

Following its commitments under the CBD, the Habitats Directive came into force [68]. The directive is concerned with the development of a network of Special Areas of Conservation (SAC) for specific habitat types and species in which biodiversity is prioritised. The Natura 2000 network, which is comprised of Habitats Directive SACs and Birds Directive SPAs, is the largest network of reserves in the world, and its development was seen as a major achievement of 
the Biodiversity Action Plan. Sites are designated according to the presence of particular target habitats or species listed in the Annexes of the directive. Despite its size the Natura 2000 network has had mixed success; $60 \%$ of species and $77 \%$ of habitats covered by the directive are reported to be in unfavourable condition [36]. The Natura 2000 network has also fallen far short of its targets in assigning protected status to agricultural areas. On a Europe wide basis only $11.5 \%$ of the agricultural area targeted to be designated as SAC have been assigned [69]. Though the Habitats Directive arose from the CBD, and was published in the same year, it may be considered as a hybrid of Pure and Popular in terms of its norms because it includes a mix of obscure and popularly unrecognised species (e.g. Dytiscus latissimus a diving aquatic beetle) which provides neither cultural nor provisioning services, as well as charismatic species (for example all species of whales are protected under the directive) and the process of designation of species for inclusion within the Annexes of the directive, through expert judgement included value based as well as ecologically based decisions [70].

The Marine Strategy Framework Directive (MSFD) [71] aims to achieve Good Environmental Status for each of 11 qualitative descriptors, uniting several environmental directives for the marine environment, these include WFD, along with the Nitrates Directive and CAP, the habitats directive and the CFP. The MSFD uses the language of the ecosystem based approach and recognises the concepts of ecosystem services and may be seen as a hybrid of all three norms, with its descriptor on fisheries being aligned with the practical focus of the CFP, the eutrophication criteria aligned with the Pure focus on the pristine environment of the WFD while the incorporation of ecosystem services (including cultural services) recognises the Popular nature of public goods. In practice, during the first round of application, the approach of many member states has been to collate the measures taken under existing directives and attribute them as measures in the implementation of the MSFD. Despite the high goals of the directive economic constraints have overridden the incorporation of new measures to incorporate ecosystem services into implementation in many cases e.g. [72].

One relatively new initiative under the EU Biodiversity strategy, and stemming from European obligations under the CBD has been the introduction of the recent regulation on Invasive Alien Species (IAS) [73]. For the purposes of the directive an alien species is "any live specimen of a species. . . introduced outside of its natural range". The objective of the law is "to prevent, minimise and mitigate the adverse impact on biodiversity of the introduction and spread of invasive alien species". This law obliges member states to prevent the establishment and control the spread of non-native species around Europe. The particular species to be addressed are contained within a list of European concern. The current, first list [74] differs from the "list of 100 worst alien invasive species" [75] in that it omits species, such as the Pacific Oyster (Crassostrea gigas), which are of economic importance but also considered invasive. While the language of the directive does recognise ecosystem service concepts, the emphasis in ecology on the concept of non-native species and the narrative of invading aliens has been heavily criticised [76], and the evolution of invasion science in the 1990s is closely linked with the coining of the term biodiversity [77]. This regulation includes some exceptions for species of economic importance in aquaculture under the Regulation concerning use of alien and locally absent species in aquaculture [78], which provides a loophole to prioritize aquaculture development over environmental integrity. While the theory behind invasive species research certainly falls into the normative category of Pure, the list of species of union concern also reflects the practical norm and the regulation may therefore be seen as a hybrid of Practical and Pure.

\section{Conclusions}

The use of ecosystem services concepts in the policy analysis above marks a novel development in methodology for developing explicit recognition of norms within policy. The methodology has been used retrospectively to analyse existing policies. The analysis reveals a range of competing norms and contradictory objectives in European environmental policy that have emerged reactively over the course of the formation and development of the EU.

The first EU Biodiversity Action Plan met with limited success, its target of halting biodiversity loss by 2010 was not achieved [79], the EU Biodiversity Strategy aims to halt this loss by 2020 . The aim of this paper was to identify underling norms in EU environmental policy which might affect implementation of the EU Biodiversity Strategy. The competing norms underlying EU environmental law have shifted from the "Practical" through "Popular" toward "Pure" and increasingly represent a range of norms, but the fundamental challenges to achieving sustainability in the frame of European environmental law remain implicit trade-offs between Practical provision of food and Pure protection of nature.

Within Europe, the funding available for implementation for practical policies eclipses funding for focussed environmental legislation. The major relationship between humans and the environment promoted by EU, the two main Practical policies (CAP an CFP) is one of consumption. Efforts to reduce the amount of environmental damage of the major Practical policies have been compromised by political negotiation to ensure the economic livelihoods of small farmers and of fishers. As demonstrated by negotiations in the CAP and CFP, politicians, on a five-year re-election cycle lack the agency to impose costs on their constituents for the purposes of poorly understood concepts such as biodiversity and ecosystem services. For fisheries and agriculture, despite recent reform, economic gains are more immediately felt than environmental gains, and production of private goods is more profitable than production of public ones. Under the current system food production is favoured 
over biodiversity conservation, and conservation is generally economically irrational, that is, individuals do not stand to increase their own economic welfare by protecting the environment. Strategies for incorporating effective biodiversity conservation into the Practical polices are therefore a clear area for targeted further research.

The "intrinsic worth" of biodiversity, as articulated by the CBD, is not necessarily self-evident, and there are not clear links between all components of nature and well-being. Though limited data exist at the European scale, at least for the marine environment, public understanding and awareness of environmental problems is poor [36]. This imbalance could be redressed through education to develop public understanding of the benefits of nature, to better align the Popular and Pure environmental norms.

The emerging focus on ecosystem services for example in the MSFD may provide a mechanism to balance these trade-offs. While full accounting for ecosystem service values and internalisation within European policy can in theory more fully elucidate and re-balance these tradeoffs, (as advocated by the MSFD) scientific understanding of the role of biodiversity in the supply of ecosystem services remains low $[24,80]$. Scientists therefore have a role in elucidating these links through further research and effectively communicating their findings to a policy makers and to the public.

In contrast to funding for rural development and fisheries exploitation, at the European level there is no dedicated centralised organisation for the funding enforcement of environmental legislation. While the European Environment Agency has a duty "to support sustainable development and to help achieve significant and measurable improvement in Europes environment through the provision of timely, targeted, relevant and reliable information to policy-making agents and the public". it has no mandate or means to enforce regulation. This responsibility instead falls to national and local governments. Existing legislation might be enforced more effectively through rebalancing the sustainable growth budget toward centralised financial support for environmental protection outside of the sectoral CAP and CFP policies.

Even within environmental legislation loopholes exist, the designation of heavily modified water bodies, the exceptions in the IAS regulation, the trade-off between economy and environment have already been made at the legislative and policy level.

\section{Outlook}

\subsection{Agency and Irrational Trade-offs}

At the individual level the goal of halting biodiversity loss, along with achieving the other indivisible SDGs come down to choices in consumption. In order to achieve these goals European individuals may be required, to make personal sacrifices for long term, greater good, to act against short- term self-interest in the cause of equity. Reducing levels of consumption may require individuals to make choices from which they personally do not benefit. This is a "wicked problem" it requires moral judgements and result in winners and losers. While science, can expose the resource constraints of a finite planet [81] it is not best suited to making moral choices or subjective decisions as it has sometimes attempted (e.g. [8,9,82]).

In this case agency requires an organisation which can effectively encourage individuals to make personal sacrifices, moral not rational choices. Markets discourage such moral behaviours [83], and the precursors of modern sustainability science has had a chequered past in this area of morality. Traditionally religious institutions could encourage or impose such choices about consumption and the major European religious institutes are beginning to engage with the environment as a moral issue [84].

This history of European environmental legislation provides evidence that European approaches toward sustainability are evolving, and that some achievements have been made, for example with the shift towards the concepts of ecosystem based management under the MSFD, it also suggests that major challenges to achieving the SDGs lie ahead. Whether the European Union (with its origins as a trading organisation) has the will, or the mandate to make the changes to key Practical policies or to force the difficult trade-offs between consumption and biodiversity that are required to meet the mission of the SDGs and of the Biodiversity Strategy remains to be seen.

The identification of competing norms and contradictory principals in this analysis provides a starting point from which European institutions can build policy coherency. The method may facilitate the proactive adaptation of existing policies and the design of new types of policy that more fully recognise and integrate the multiple Practical, Popular and Pure objectives and norms which are reflected in the SDGs and which are required to meet the goals of halting biodiversity loss in Europe.

In order to develop a truly integrated and effective approach to meeting the targets of the EU Biodiversity Strategy the norms relating to the provisioning and cultural ecosystem services of the Practical and Popular sets should be aligned with the policies of the Pure set. We need to make Pure more Popular, by improving public understanding of the environment (and thereby increasing cultural ecosystem services) and Practical more Pure by finding techniques of resource extraction that are less destructive. Explicit consideration of these differing norms provides a basis for further analysis. Ecosystem services concepts offer one potential avenue for moving past trade-offs between economic gain versus "intrinsic" worth, yet difficult trade-offs may still remain. European policy makers, scientists, educators and religious institutions all have roles to play and Europe may need to re-engage with concepts of morality rather than economy or ecology to achieve its conservation goals. 


\section{References and Notes}

[1] Convention on Biodiversity; 1992. Available from: https://www.cbd. int/.

[2] From the Istanbul Programme of Action to the 2030 Agenda for Sustainable Development. United Nations Publications; 2016. 10.18356/86ae54d1-en.

[3] Wackernagel M, Schulz NB, Deumling D, Linares AC, Jenkins M, Kapos V, et al. Tracking the ecological overshoot of the human economy. Proceedings of the National Academy of Sciences. 2002:99(14):9266-9271. doi:10.1073/pnas.142033699.

[4] Ewing B, Moore D, Goldfinger S, Oursler A, Reed A, Wackernagel M. Ecological footprint atlas. 2010.

[5] Cardinale BJ, Duffy JE, Gonzalez A, Hooper DU, Perrings C, Venail $P$, et al. Biodiversity loss and its impact on humanity. Nature. 2012;486(7401):59-67. doi:10.1038/nature11148.

[6] Jentoft S, Chuenpagdee R. Fisheries and coastal governance as a wicked problem. Marine Policy. 2009;33(4):553-560. doi:10.1016/j.marpol.2008.12.002.

[7] Cohen JE. Population growth and earth's human carrying capacity. Science. 1995;269(5222):341.

[8] Ehrlich PR, Holdren JP. Impact of Population Growth. Science. 1971 mar;171(3977):1212-1217. Available from: http://dx.doi.org/10.1126/ science.171.3977.1212. doi:10.1126/science.171.3977.1212.

[9] Hardin G. Commentary: Living on a LIFEBOAT. BioScience. $1974 ; 24(10): 561-568$.

[10] Wang C. History of the Chinese family planning program: 1970-2010. Contraception. 2012;85(6):563-569.

[11] Evenson RE, Gollin D. Assessing the impact of the Green Revolution, 1960 to 2000. Science. 2003;300(5620):758-762.

[12] Pingali PL. Green Revolution: Impacts, limits, and the path ahead. Proceedings of the National Academy of Sciences. 2012;109(31):12302-12308. doi:10.1073/pnas.0912953109.

[13] Nixon SW. Coastal marine eutrophication: a definition, social causes, and future concerns. Ophelia. 1995;41(1):199-219.

[14] Vitousek PM, Mooney HA, Lubchenco J, Melillo JM. Human domination of Earth's ecosystems. Science. 1997;277(5325):494-499.

[15] Tilman D, Cassman KG, Matson PA, Naylor R, Polasky S. Agricultural sustainability and intensive production practices. Nature. 2002;418(6898):671-677. doi:10.1038/nature01014.

[16] Mee L. Reviving Dead Zones. Scientific American. 2006;295(5):7885. doi:10.1038/scientificamerican1106-78.

[17] Ménesguen A, Perrot T, Dussauze M. Ulva Mass Accumulations on Brittany Beaches: Explanation and Remedies Deduced from Models. Mercator Ocean Quartely Newsletter. 2010;38:4-13.

[18] Hering D, Borja A, Carstensen J, Carvalho L, Elliott M, Feld CK, et al. The European Water Framework Directive at the age of 10: a critical review of the achievements with recommendations for the future. Science of the total Environment. 2010;408(19):4007-4019.

[19] Ehrlich PR, Wilson EO. Biodiversity studies: science and policy. Science. 1991;253(5021):758.

[20] Assessment ME. Ecosystems and human well-being. vol. 200. Washington, DC, USA: Island Press; 2003.

[21] Kumar P. The Economics of Ecosystems and Biodiversity: ecological and economic foundations. UNEP/Earthprint; 2010.

[22] Hanley N, Barbier EB, Barbier E. Pricing nature: cost-benefit analysis and environmental policy. Edward Elgar Publishing; 2009.

[23] Hooper DU, Chapin F, Ewel J, Hector A, Inchausti P, Lavorel S, et al. Effects of biodiversity on ecosystem functioning: a consensus of current knowledge. Ecological monographs. 2005;75(1):3-35.

[24] Mace GM, Norris K, Fitter AH. Biodiversity and ecosystem services: a multilayered relationship. Trends in ecology \& evolution. 2012;27(1):19-26.

[25] Raudsepp-Hearne C, Peterson GD, Tengö M, Bennett EM, Holland $\mathrm{T}$, Benessaiah K, et al. Untangling the environmentalist's paradox: why is human well-being increasing as ecosystem services degrade? BioScience. 2010;60(8):576-589.

[26] The EU Biodiversity strategy 20 2020. European Comission; 2011.

[27] Communication from the commission halting the loss of biodiversity by 2010 and beyond sustaining ecosystem services for human well-being. Brussel, Belgium: European Comission; 2006.

[28] Vogler J. The European Union 1 as an actor in international environ- mental politics. Environmental Politics. 1999;8(3):24-48.

[29] The Mid-term review of the EU Biodiversity Strategy. Brussel, Belgium: European Comission; 2015.

[30] Wiek A, Farioli F, Fukushi K, Yarime M. Sustainability science: bridging the gap between science and society. Sustainability Science. 2012;7:1-4.

[31] Wiek A, Iwaniec D. Quality criteria for visions and visioning in sustainability science. Sustainability Science. 2014;9(4):497-512.

[32] Giddings B, Hopwood B, O'brien G. Environment, economy and society: fitting them together into sustainable development. Sustainable development. 2002;10(4):187-196.

[33] Garcia SM. Fisheries assessment and decision-making: towards an integrated advisory process. The ecosystem approach to fisheries CABI, Wallingford, UK and Food and Agriculture Organization of the United Nations, Rome. 2008;pp. 158-196.

[34] Kahneman D, Knetsch JL. Valuing public goods: the purchase of moral satisfaction. Journal of environmental economics and management. 1992;22(1):57-70.

[35] Potts T, Pita C, O'Higgins T, Mee L. Who cares? European attitudes towards marine and coastal environments. Marine Policy. 2016;72:59-66.

[36] The European environment-State and outlook. Copenhagen, Denmark: European Environment Agency; 2015. Synthesis Report.

[37] Zahrnt V. Food security and the EU's Common Agricultural Policy: Facts against fears. ECIPE (European Centre for International Political Economy) Working paper. 2011;(1):23.

[38] Borrell B, Hubbard L. Global economic effects of the EU Common Agricultural Policy. Economic Affairs. 2000;20(2):18-26.

[39] Kleijn D, Sutherland WJ. How effective are European agrienvironment schemes in conserving and promoting biodiversity? Journal of Applied Ecology. 2003;40(6):947-969. doi:10.1111/j.13652664.2003.00868.x.

[40] Note: European Council Conclusions on the Multiannual Financial Framework 2014-2020 and the CAP. Brussels, Belgium: European Parliament, Directorate-General for Internal Policies, Policy Department B; 2013.

[41] Communication from the commission to the European parliament, the council, the European Economic and social committee and the committee of the regions The CAP towards 2020: Meeting the food natural resources and territorial challenges of the future. Brussels 18.11.2011 COM (2010) 672 Final. 2010.

[42] Pe'er G, Dicks LV, Visconti P, Arlettaz R, Baldi A, Benton TG, et al. EU agricultural reform fails on biodiversity. Science. 2014;344(6188):1090-1092. doi:10.1126/science.1253425.

[43] Council regulation (EEC) No 180 of 25 January 1983 laying down certain interim measures for the conservation and management of fishery resources applicable. Official Journal of the European Communities. 1983; L24/ 26.

[44] Regulation (EU) No 1380/2013 of the European parliament and of the council of 11 December 2013 on the common fisheries policy. Official Journal of the European Commission. 2002; L354/22.

[45] Regulation (EU) No 1380/2013 of the European parliament and of the council of 11 December 2013 on the common Fisheries Policy. Official Journal of the European Union. 2013; L354/22.

[46] Daw T, Gray T. Fisheries science and sustainability in international policy: a study of failure in the European Union's Common Fisheries Policy. Marine Policy. 2005;29(3):189-197.

[47] Carpenter G, Kleinjans R, Villasante S, O'Leary BC. Landing the blame: The influence of EU Member States on quota setting. Marine Policy. 2016;64:9-15.

[48] Communication from the commission to the European Parlaiment, the council, the european economic and social committee and the committee of the regions. On Reform of the Common Fisheries Policy. European Comission, 2011. COM/2011/0417 final */.

[49] Status of marine fish stocks. European Environmental Agency, 2016. Available from: http://www.eea.europa.eu/data-and-maps/indicators/ status-of-marine-fish-stocks-2/assessment.

[50] Monitoring the performance of the Common Fisheries Policy (STECF15-04), Publications Office of the European Union, Luxembourg, 2015.

[51] The Schuman Declaration, 1950. Available from: http: //europa.eu/about-eu/basic-information/symbols/europe- 
day/schuman-declaration/index_en.htm.

[52] EU annual budget life-cycle: Figures. Available from: http://ec.europa. eu/budget/annual/index_en.cfm.

[53] European Economic Community Council directive 76/160/EEC of 8 December 1975 concerning the quality of bathing water. Official Journal of the EEC. 1976; L031.

[54] European Economic Community Council Directive 79/409/EEC of 2 April 1979 on the conservation of wild birds. Official Journal of the EEC. 1979; C24.

[55] European Comunity Directive 2009/147/EC of the European Parliament and of the council of 30 November 2009 on the conservation of wild birds (codified version) Official Journal of the European Union. 2009; L20/7.

[56] Donald PF, Pisano G, Rayment MD, Pain DJ. The Common Agricultural Policy, EU enlargement and the conservation of Europe's farmland birds. Agriculture, Ecosystems \& Environment. 2002;89(3):167182.

[57] Eurostat, 2015. Agri-environmental indicators-population trends of farmland birds. Available from: http://ec.europa.eu/eurostat/ statistics-explained/index.php/Agri-environmental_indicator_population_trends_of_farmland_birds.

[58] Eropean Comission Directive 2000/60/EC of the European Parliament and of the Council of 23 October 2000 establishing a framework for Community actions in the field of water policy. Official Journal of the European Communities. 2000; L327, 1.22.12.2000.

[59] Borja Á, Elliott M, Carstensen J, Heiskanen AS, van de Bund W. Marine management-towards an integrated implementation of the European Marine Strategy Framework and the Water Framework Directives. Marine Pollution Bulletin. 2010;60(12):2175-2186.

[60] Bennion H, Battarbee RW, Sayer CD, Simpson GL, Davidson TA. Defining reference conditions and restoration targets for lake ecosystems using palaeolimnology: a synthesis. Journal of Paleolimnology. 2011;45(4):533-544

[61] Bouleau G. The WFD dreams: Between ecology and economics. Water and Environment Journal. 2008;22(4):235-240.

[62] Duarte CM, Conley DJ, Carstensen J, Sánchez-Camacho M. Return to Neverland: shifting baselines affect eutrophication restoration targets. Estuaries and Coasts. 2009;32(1):29-36.

[63] Kampa E, Hansen W. Heavily Modified Water Bodies: Synthesis of 34 Case Studies in Europe with 19 Figures and 49 Tables. Springer Science \& Business Media; 2004.

[64] Nitrates Directive, 91/676/EEC. Commission of the European Communities, Brussels, Belgium. 1991.

[65] O'Higgins T, Farmer A, Daskalov G, Knudsen S, Mee L. Achieving good environmental status in the Black Sea: scale mismatches in environmental management. Ecology and Society. 2014;19(3). doi:10.5751/es-06707-190354

[66] Velthof G, Lesschen J, Webb J, Pietrzak S, Miatkowski Z, Pinto M, et al. The impact of the Nitrates Directive on nitrogen emissions from agriculture in the EU-27 during 2000-2008. Science of the Total Environment. 2014;468:1225-1233.
[67] Urban Wastewater Treatment Directive, 91/271/EEC. Commission of the European Communities, Brussels, Belgium. 1991.

[68] Council Directive 92/43/EEC of 21 May 1992 on the conservation of natural habitats and of wild fauna and flora. Official Journal of the EEC. 1992; L206/7 1.

[69] Agri-environemental indicator-Natura 2000 agricultural areas.

[70] Bryan S. Contested boundaries, contested places: The Natura 2000 network in Ireland. Journal of Rural Studies. 2012;28(1):80-94.

[71] Directive 2008/56/EC of the European Parliament and of the Council of 17 June 2008 establishing a framework for community action in the field of marine environmental policy. Official Journal of the European Union. 2008.2 L 164/19.

[72] Environment, Community and Local Government. Marine Strategy Framework Directive. Ireland. Programme of Measures Summary Report. Dublin Ireland; 2016.

[73] Regulation (EU) no 1143/2014 of the European Parliament and of the council of 22 October 2014 on the prevention and management of the introduction and spread of invasive alien species. Official Journal of the European Union. 2014 L317/35.

[74] Commission implementing regulation (EU) 2016/1141 of 13th of July 2016 adopting a list of invasive alien species of Union conern pursuant to Regulation (EU) No 1143/2014 of the European Parlaiment and Council. Official Journal of the European Union L 189/4.

[75] Lowe S, Browne M, Boudjelas S, De Poorter M. 100 of the world's worst invasive alien species: a selection from the global invasive species database. Aliens. 2000;12:1-12.

[76] Davis MA, Chew MK, Hobbs RJ, Lugo AE, Ewel JJ, Vermeij GJ, et al. Don't judge species on their origins. Nature. 2011;474(7350):153154.

[77] O'Higgins T. It's not easy being green: a systems approach to environmental management. Edingburg, UK: Dunedin Academic Press; 2015.

[78] Council Regulation (EC) No 708/2007 of 11 June 2007 concerning use of alien and locally absent species in aquaculture. Official Journal of the European Union. 2007; L168/1.

[79] Report from the commission to the council and the European parliament the 2010 assessment of implementing the EU Biodiversity Action Plan COM(2010) 548 final 2010.

[80] Harrison P, Berry P, Simpson G, Haslett J, Blicharska M, Bucur M, et al. Linkages between biodiversity attributes and ecosystem services: a systematic review. Ecosystem Services. 2014;9:191-203.

[81] Rockström J, Steffen W, Noone K, Persson Å, Chapin FS, Lambin EF, et al. A safe operating space for humanity. Nature. 2009;461(7263):472-475. doi:10.1038/461472a.

[82] Ehrlich PR. The Population Bomb. Ballantine Books address=New York, NY, USA, year $=1968$.

[83] Falk A, Szech N. Morals and markets. science. 2013;340(6133):707711.

[84] Francis P. Laudato si: On care for our common home. Our Sunday Visitor; 2015. 